\title{
sciendo
}

\section{PLAY AS ART OF SURVIVAL}

\section{DÁŠA ČIRIPOVÁ}

Institute of Theatre and Film Research,

Art Research Centre of the Slovak Academy of Sciences, Bratislava

\begin{abstract}
The study explores the art of performance and happening in Slovakia from the 1960s, and its influence on theatre. Given its interdisciplinarity, the first part is dedicated to the vantage points of performance in Slovakia: action art and related names. Action art had significant influence on later theatre performative forms. The second part focuses in detail on actions and performances by the company Temporary Society of Intense Experience, Balvan Theatre and on the artist Miloš Karásek.

Key words: performance, action art, Happsoc, Temporary Society of Intense Experience [Dočasná spoločnost̉ intenzívneho prežívania, DSIP], Ján Budaj, L’ubomír Ďurček, Balvan, Michal Murin, Miloš Karásek
\end{abstract}

The art theorist and art historian Ján Kralovič, in his Majstrovstvo za dverami [Championship behind the Door], portrays art in the 1970s and 1980s, and focuses on the action Majstrovstvá Bratislavy v posune artefaktu [Bratislava Championship in Shifting the Artifact]. He contextualises alternative art manifestations of the time: "An alternative was an attempt to retain the very nature of art - art as free activity that reflects reality by using individual transformation of an author in order to transform the reality into metaphor, or by using the reality as an archetype referring to variable and heterogeneous life situations." ${ }^{\prime 1}$

The Bratislava Championship was held intermittently from 1979 to 1986, drawing together virtually all artists who stood outside the official art scene. The action came upon the initiative by the visual artist Dezider Tóth. In 1967, Tóth founded the theatre Pomimo - Divadlo po Einsteinovi [Elsewhere - Theatre after Einstein] to explore the limits between a completed object, visual poetry and theatre experiment. With his humour and travesty Tóth built upon the legacy of Dada, Fluxus intermedia overlaps and the theory of relativity: "We ought to come, quite accurately, to the same result as did Albert. A star isn't where we see it ... A star, genuine star, is a bit, tiny little bit ... elsewhere ... It may seem that you are following your aim, though in fact, you are going ... elsewhere ... Theatre is in jeopardy too, as pointed out by the founder of Merz theatre Kurt Schwitters some time ago." ${ }^{2}$

Ján Kralovič drew from the voluminous studies of the art historian Zora Rusinová. In 2001 she held, in the Slovak National Gallery, an exhibition Art of Action 1965 -

\footnotetext{
${ }^{1}$ KRALOVIČ, Ján. Majstrovstvo za dverami [A Contest behind the Door]. Bratislava : Slovart, Vysoká škola výtvarných umení, 2017, p. 33. ISBN 9788055627311.

${ }^{2}$ RUSINOVÁ, Zora. Umenie akcie 1965 - 1989 [The Art of Action 1965 - 1989] (a catalogue for the exhibition Art of Action 1965 - 1989. 26 April - 19 August 2001)]. Bratislava : Slovenská národná galéria, p. 104.
} 
1989, accompanied by an eponymous catalogue. Kralovič and Rusinová argue that Slovak alternative art emerged not as a premeditated activity, but as an effort that arose from individual needs of artists and their self-identification vis-à-vis the official scene through play, inter-artistic communication or contact, and concept. ${ }^{3}$ In an attempt to define the notion of art of action, Rusinová offers, along with the Polish action artist Zbygniew Warpechowski, a term performance that is closely linked to and is part of the art of action. Conscious of the extensive scope the notion embraces, both authors identify the difference between performance and art-performance. Artperformance comprises an action or event that is somewhat connected to the context of art, being linked or otherwise related to it. "Freedom of expression doesn't suffice, an artist ought to have a sense of responsibility, too," ${ }^{4}$ suggests Rusinová.

Rusinová links the beginning of action art to the post-WWII emergence of certain antithesis to classical types of artistic manifestation, turning to understanding and penetrating everyday reality. The trends had their additional root in interwar avantgarde - Dada, Futurism, Russian avantgarde, Bauhaus, and Fluxus that followed on them in the 1950s. Fluxus itself was preceded by happening - new artistic trend coined in 1958 by the US visual artist Alan Kaprow in student magazine Anthology. Kaprow argued that happening was an assemblage of an event, either finalised or perceived in different times and places. "We understand action (happening, performance, event) as fashioning presence (...), (...) it is a reference to the 'here' reality (hic et nunc)." ${ }^{5}$ Unlike stage play, a happening can be held in a supermarket, whilst driving on a motorway, in a friend's kitchen, either simultaneously or in sequence.

It is the very year, in 1958, that happening enters European context, namely in Paris where the sculptor and painter Wolf Vostell held a street action Das Theater ist auf der Strasse [The Theatre Is on The Street]. Vostell invited passers-by to imitate poster cutting that read: "walk along the street, read gradually the texts and lettering on the torn posters." Fluxus, an international group or rather movement, emerged in New York shortly afterwards. The leitmotiv was to be forthcoming to the spectator. Since the very meaning of flux is movement, action, continuous change, participants presented works that were epitomised by movement, action, incessant change, though all that with a discernible concept.

Within the Slovak context, performance and happenings emerged in the early 1960s, in parallel with international developments. Similar actions at the time were held, for instance, in Wuppertal (Joseph Beuys held his 24-hour happening) or in Berlin (René Block hosted Concert Fluxus). Slovak artists held a range of events and actions in both private and public space. Yet they didn't follow the Kaprow model of happening, wishing to distance themselves from the trend. Instead, they leaned towards the Prague movement Aktual. ${ }^{6}$ As early as 1958, the visual artist Vladimír Popovič co-founded Divadlo objektov [The Objects Theatre], bringing together elements from theatre, music and visual arts.

\footnotetext{
${ }^{3}$ Ibid., p. 3.

${ }^{4}$ Ibid.

${ }^{5}$ KRALOVIČ, Ján. Stopa na dlažbe: Umenie akcie v mestskom priestore v rokoch 1965 - 2000 na Slovensku [A Trace on the Pavement: Art of Action in Urban Space in Slovakia in 1965 - 2000] (doctoral thesis). Trnava : Filozofická fakulta Trnavskej univerzity, 2012, p. 3.

${ }^{6}$ See EURINGER-BÁTOROVÁ, Andrea. Akčné umnie na Slovensku v 60. rokoch 20. storočia [Action Art in Slovakia in the 1960s]. Bratislava : Slovart, 2012, p. 57. ISBN 978-80-556-0438-1.
} 
Slovak art history defines art of action as art close to performance, art of live performance of events or storyline within set space and time, with possible active or passive participation by spectators (or without them). In their nature, the activities bring together a number of layers (time, space, body, movement, gesture, and sensation), reaching to the level of mental and physical contact with the context and material. Art of action accentuates the sequence of event and experience it offers. ${ }^{7}$ Kralovič points out that "The choice of context is not random, it is an element of the concept of action." ${ }^{\prime 8}$ Unforeseen situations transform the venue of the event and its denotation. Action art operates with the principle of the unexpected, spontaneous, with coincidence or improvisation. Urban action is open wide to social interaction and participation.

Rusinová suggests that action art awakens "concealed instincts; it is energy that uses rudimentary gesture to reveal unsuspected layers of personal and social mythology." 9 Artists thus refer indirectly to Johan Huizinga's Homo Ludens - the inexorableness of play in the development of mankind: "Human culture is born out of and develops in play and as a play." ${ }^{10}$ Between the 1960s and 1980s, the principle of play had the power to eliminate the border between art and anti-art, for artists used play to create briefly a different reality. Kralovič defines the process as "interference of an event in the domain of the extraordinary" - a play literary enabled the artists to survive. ${ }^{11}$

Michal Murin, who was involved in action art in the 1980s and 1990s, suggests that Slovak action art and its participants could be identified as having formed a number of circles. One generation brought together artists ranging from Alex Mlynárčik and Stano Filko, through Július Koller, Milan Adamčiak, Róbert Cyprich, to Rudolf Sikora. Though the generation may seem uniform, some members were as much as fifteen years apart in age. Peter Bartoš, Michal Kern, Dezider Tóth devised altogether different strategy, whilst Lubomír Ďurček and Ján Budaj opted for yet different approach that further differed from that used by Peter Meluzin and Vladimír Kordoš. Each approached action art differently. Kordoš, for instance, held his actions largely as photo actions; Budaj was essentially connected with different forms of street theatre; Bartoš was an eccentric introvert; Adamčiak withdrew into silence in between 1971 and 1988; Filko emigrated to the USA in 1981; Mlynárčik engaged in architectural design in order to finance his actions held for dozens of participants at the time when as few as five artists were afraid to gather in Bratislava to avoid being interrogated the next day. ${ }^{12}$

In the 1960s, artistic activities by Slovak visual artists (particularly Adamčiak, Mlynárčik, Filko, Koller, Cyprich, or Durček) reached beyond the extent of fine art.

\footnotetext{
${ }^{7}$ Ibid., pp. $34-57$.

${ }^{8}$ KRALOVIČ, Ján. Stopa na dlažbe: Umenie akcie v mestskom priestore v rokoch 1965 - 2000 na Slovensku [A Trace on the Pavement: Art of Action in Urban Space in Slovakia in 1965 - 2000] (doctoral thesis), p. 2.

${ }_{9}^{9}$ RUSINOVÁ, Zora. Umenie akcie 1965 - 1989 [The Art of Action 1965 - 1989] (a catalogue for the exhibition Art of Action 1965 - 1989. 26 April - 19 August 2001), p. 9.

${ }^{10}$ HUIZINGA, Johan. Homo ludens. O puivodu kultury ve hře [Homo Ludens. A Study of the Play-Element in Culture]. Praha : Mladá fronta, 1971.

${ }^{11}$ Ibid., p. 7

${ }^{12}$ MURIN, Michal - STOLÁRIK, Michal. Akčné umenie a performance na Slovensku. Rozhovor s Michalom Murinom. [Action Art and Performance in Slovakia. An interview with Michal Murin]. In Festival Performaction, 2010, p. 4. ISBN 9788089078769. Available at https://monoskop.org/images/2/27/Festival_Performaction_2010.pdf [cit. 12 June 2018].
} 
They were exemplified by elements of theatre. Today we would refer to the works as to performance, installation or immersion theatre. ${ }^{13}$ In 1965, Alex Mlynárčik held, together with Stano Filko, an action Happsoc I. (happen society). It was a permanent ironic identification - mystification of what was presented as happy Communism, happy communisation. The action was accompanied by a manifesto: "Happsoc was a challenge of mental activity based on actual event ... An action invited a perception of reality as removed from the stereotype of existence. The found reality, set in time and place, generated an effect through its inner relationships and tensions."14

On another project, entitled Permanentné manifestácie [Permanent Manifestations], Mlynárčik writes: "Permanent manifestations are an action of a limited or unlimited group, participants in an event. The situation anticipates, on the part of spectator, a greater or smaller urge to direct participation. An author creates objects, gestures, context, processes that are conducive to a free creative act, and to inspire creative co-participation of an anonymous or identified partner. The degree of co-creation is unlimited."15 The French art theorist Pierre Restany who followed particularly the actions held by Mlynárčik, points out that "at these points, art is not merely an avantgarde discharge or revolt, but - first and foremost - an art of participation." 16

The process of the re-instalment of orthodox Communism in the 1970s in Czechoslovakia after the suppression of Prague Spring by the invasion of Warsaw Pact troops in August 1968 fundamentally affected activities on the official art scene. Yet, in the early 1970s, unofficial scene continued to still somewhat enjoy the echo of the relaxed atmosphere of the late 1960s. That enabled holding such major events as Polymúzický priestor [Polymusic Space, 1970], Festival snehu [Festival of Snow, 1970], Otvorený ateliér [Open Atelier, 1970]; happenings and group actions by Alex Mlynárčik: Juniáles - Sviatočné hody [Juniáles - Festive Feast, 1970], Deň radosti - Keby všetky vlaky sveta... [A Day of Joy - If All the Trains of the World ...1971], Memoriál Edgara Degasa [The Edgar Degas Memorial, 1971]; Jana Želibská: Snúbenie jari [The Betrothal of Spring, 1970]. ${ }^{17}$ For instance, at the June happening The Betrothal of Spring, in which Adamčiak joined Želibská, participants were invited to bring whistles and responded freely to the theme (the betrothal of Spring and Summer). The event was held in an atmosphere of collective celebration and play. A number of critics argued that it removed the participants from everyday situations and briefly reinstated the sense of freedom and joy. In 1970 Ensemble Comp. held an intermedia happening in an indoor swimming pool at a university dorm Bernolák in Bratislava. In homage to Georg Friedrich Händel they performed Vodná hudba - skladba pre tri sláčikové nástroje a xylogóny [The Water Music - a suite for three strings and xylophone]. The perform-

${ }^{13}$ Michal Murin is interested, inter alia, in art terminology and introduction of new terms into the practice of art. It wasn't until 1993 that, in line with the US art history terminology, he identified the art of the late 19880s and 1990s as performance. He included in the term the art of action, event, happening. "Until then, the artists involved in action art used the term performance as dishonour, as something plebeian." See MURIN, Michal - STOLÁRIK, Michal. Akčné umenie a performance na Slovensku. Rozhovor s Michalom Murinom [Action Art and Performance in Slovakia. An interview with Michal Murin], p. 5.

${ }^{14}$ JANČÁR, Ivan. Alex Mlynárčik. Bratislava : Slovart, Krása, Galéria mesta Bratislavy, 2014, p. 127. ISBN 9788089340620.

15 Ibid.

${ }^{16}$ KRALOVIČ, Ján. Stopa na dlažbe: Umenie akcie v mestskom priestore v rokoch 1965 - 2000 na Slovensku [Trace on the pavement: Art of Action in Urban Space in Slovakia in 1965 - 2000] (doctoral thesis), p. 9.

${ }_{17}$ ŠIMEČKA, Milan. Obnovenie poriadku [Restating the Order]. Bratislava : Archa, 1990. 
ers Milan Adamčiak, Róbert Cyprich and Jozef Revallo played above and under the water surface, and anticipated spectators' participation. Having first performed in the hall of the swimming pool, they then dived - along with their instruments - into the pool. Spectators were invited to dive in and play on the xylophones placed on the bottom of the pool. The spectators thus gradually became both participants and makers of the event. ${ }^{18}$ In Evina svadba [Eve's Wedding by Mlynárčik, 1972], happy reality as experienced within the framework of the work of art - an action - acquires the shape of celebration. The action Sláčiky pre Petra Ondreičku [Strings for Peter Ondrejička] by Dezider Tóth and his friends was held in a more intimate setting (1971). The artist no longer creates new reality but adopts the reality of life ("joins its flow"), thus raising the noble nature of the actual. The moment of making the tension of the extraordinary more special appears as somewhat ritualised nature of the event that is not a matter of everyday life. ${ }^{19}$

In 1972, after the November congress of the Union of Slovak Fine Artists, progressive artists and critics who made their name in the 1960s were accused of formalism and intentional disorientation of artistic community. The style of Socialist Realism continued to govern the official art. It was the only officially endorsed style as the single creative method of Communist art. That inevitably undermined any drive towards more progressive artistic activities. ${ }^{20}$

In the catalogue for the exhibition Umenie akcie 1965 - 1989 [The Art of Action 1965 - 1989], Ján Budaj points out that action art gradually lost the "utopian, festive, carefree collective rituals, plays and shared situations. The period after 1972 was in essence marked by two types of action: one involved presentations in studios, apartments, empty spaces, remote suburban or natural areas; the other one was part of life on the street." ${ }^{21}$ Street actions in the late 1970s were organised largely by Lubomír Ďurček and Ján Budaj and their Dočasná spoločnost’ intenzívneho prežívania, DSIP [Temporary Society of Intense Experience, DSIP]. The actions weren't merely related to the résistance to the totalitarian regime: they were also affected, to a degree, by the hippie movement and that of provo (Danish counter-culture movement), or by the Situationists' political actions. ${ }^{22}$ It was the French author of happenings Jean-Jaques Label who, together with the theatre company Living Theatre, contributed to the closure of the Paris-based theatre Odéon, the epitome of the official French culture, during the upheavals of the student movement in May 1968. Their provocative performances turned into political platform of theatre avantgarde. At the same time, Abbie Hoffman, member of the American radical political and culture movement, conceptualised demonstrations as theatre productions: flowers were given to policemen and politicians, nudity was being discovered, lifestyle energy and joy served as human struggle against fear and peril.

\footnotetext{
${ }^{18}$ See further ADAMČIAK, Milan. ZAČNI! [START!] (a catalogue for an exhibition Adamčiak, start! A retrospective of intermedia works of Milan Adamčiak 1964 - 2017, 23 March - 2 July 2017). Bratislava : Slovenská národná galéria, 2017, p. 6.

${ }^{19}$ KRALOVIČ, Ján. Stopa na dlažbe: Umenie akcie v mestskom priestore v rokoch 1965 - 2000 na Slovensku [Trace on the Pavement: Art of Action in Urban Space in Slovakia in 1965 - 2000] (doctoral thesis), p. 11.

${ }^{20}$ Za socialistické umenie [For Communist Art]. Bratislava : Slovenský spisovatel', 1974.

${ }^{21}$ Ján Budaj as quoted from RUSINOVÁ, Zora. Umenie akcie 1965 - 1989 [Art of Action 1965 - 1989] (a catalogue for the exhibition Art of Action 1965 - 1989. 26 April - 19 August 2001), p. 149.

${ }^{22} \mathrm{Ibid}$. The Situationists gave an impulse to the student movement and May revolution in Paris in 1968.
} 
DSIP sought inspiration in these activities, adapting them to their own interests and according to their perception of the denotation of action and performance. Lubomír Ďurček identified with expanded performance (performance within wider context - authenticity, performativity, theatre limits, intermediality). Budaj argues that he "often transforms his actions into photo-piece," ${ }^{23}$ where photography as a medium becomes part of the concept. Ďurček, inspired by the American performance and action artist Vito Acconci, used as a medium the plasticity of human body instead of the word. Durček understood physicality in sense of elementary form of expression as live sculpture set in urban context or nature. Ďurček's actions, in comparison with those held by Budaj or Mlynárčik, were more intimate, yet the more existentialist. For instance, in 1980 he held an action Návštevník [The Visitor] pointing to the manipulation of political ideas and the lack of freedom: he rang at the door of his friends with his mouth stuffed with the daily newspaper Pravda ${ }^{24}$ and the title Central Committee. Mira Keratová, the curator of the exhibition dedicated to L'ubomír Durček, suggests that his work "urges and inspires spectator to his own, autonomous gesture in an estranged society. [Ďurček] stages surprising situations and destroys the stereotype of a pedestrian, to induce him to more intensely experience everyday reality and to self-awareness. He is also interested in the idea of a crowd and individual conduct within: he experiments with the moment of identification (merger) with the mass and with isolation from the crowd. (...) In his total performances Durček works with sensory perception on the part of spectator, with limitation and disorientation of his senses; he directs his sensory perception and expands his sensitivity." 25

On the break of 1970s and 1980s, Ďurček worked with the amateur Labyrinth Theatre. For the action Týždeñ divadla na ulici [A Week of Theatre on the Street], held by the DSIP, he created a set of actions entitled Rezonancie [Resonances, 1979]. A team of ten performers was brought to a defined urban location in order to generate psychosocial situations in two phases: by identifying with the crowd of pedestrians and by subsequently isolation from the crowd. Performers assumed, within the shortest possible time, one of the designed figures, thus creating actual situation (a bench, knot, monument, exile, phantom, temple, etc.).

\section{The Art of Performance and Theatre Performance}

The milestone events of the late $1980 \mathrm{~s}^{26}$ and public euphoria brought along the renascence of happening that assumed the form of manifestation, declaration of opinion, hence returning to the original roots (ritual, archetype, personal mythology). It assumed more daring stance on current affairs and the issues of the day. Yet it was already the late 1970s that saw the emergence of such companies as the Divadlo Labyrint [Labyrinth Theatre, 1978], Dočasná spoločnost' intenzívneho prežívania, DSIP [Temporary Society of Intense Experience, 1979 - 198], Artprospekt P.O.P. (1979 -

\footnotetext{
${ }^{23}$ Ibid., p. 139.

${ }^{24}$ Pravda daily was the official periodical of the Central Committee of the Communist Party of Slovakia.

${ }^{25}$ See KERATOVÁ, Mira. L'ubomír Ďurček. Situačné modely komunikácie [L’ubomír Ďurček Situational Models of Communication]. Available at https://www.sng.sk/sk/vystavy/2_lubomir-durcek-situacne-modely-komunikacie [cit. 12 June 2018].

${ }^{26}$ The late 1980s, affected by revolutionary movements, brought the demise of Communism and the dawn of democratisation to the Communist bloc.
} 
1985), then the Balvan [The Boulder] Theatre (1987 - 1992), Spoločnost' pre pestovanie a šírenie patafyziky [The Society for the Development and Dissemination of Pataphysics, 1988 - 1993], Transmusic comp. (1989 - 1996), Disk Theatre (with Blaho Uhlár s. 1987), Stoka [Sewer] Theatre (1991 - 2006), GUnaGU (s. 1985), HUBRIS Theatre Company (1990 - 1994; renamed as Debris Theatre Company in 1995), Lengow \& HEyeRMEarS (1997 - 2000), and Kafron.

The Temporary Society of Intense Experience (DSIP), mentioned earlier in connection with L'ubomír Ďurček, developed from a poetry group Degenerovaná generácia (DG) [Degenerate Generation, DG], from a fragment of the amateur Labyrinth Theatre that performed within the university culture centre V-Klub in Bratislava (1975 - 1980), and with the aid of similarly-minded artists and friends. It operated at performative level within the social context. Its para-political activities that largely fall into the period of 1978 - 1980, emerged collectively, as a result of self-organisation. Most actions were carried out without the consent of official authorities and were thus deemed illegal. The interventions emerged and disappeared as 'temporary autonomous zones'. They largely focused on exploring reality and fiction, action and reaction. They often let spectators slip into absurd situations that confronted the participants with the setting and the emergent situation. The process of experience transformed spectators into participants. ${ }^{27}$

The DSIP activities were closely related to those of the Bratislava-based theatres. A range of theatre-happening etudes emerged (such as Faust, Pegasnik, Dezider Tóth's Elsewhere). Ján Budaj recalls one of them: “a number of actors wrapped themselves in white paper, creating sings amidst street flow. (...) On the nearby law, a man lied with arms and legs tied." ${ }^{28}$ Since Budaj, the founding member of DSIP, didn't have arts background, his actions differed in their powerful societal, social and environmental dimension. He explored the relationship between an individual and society. Being particularly drawn by the "psychological and sociological context of conformism as a social phenomenon," he believed in the possibility of possible transforming an individual through "intense experience of a life event." 29

The often-provocative actions held by DSIP explored public response through what fully developed during the Street Theatre Week, when all actions presented deviation from the standards of everyday reality. Zora Rusinová describes some of the DSIP actions during the Week as follows: "They managed to create a barrier in the lane between the Primate's Palace and the Main Square where the actors laid across on the ground, thus preventing pedestrians to pass through. (...) In the end, passers-by were handed a card that read: 'You took part in one of the actions of street theatre.' In yet another action, on the corner of Laurinská and Sedlárska streets, people were passing by the figure of Rachel (Vladimír Archleb) that was chained to a rail. Elsewhere, in the very city centre, they staged a lavish luncheon banquet at a massive table:

\footnotetext{
${ }^{27}$ See further https://www.ssgbb.sk/vystavy/275-pracovna-pamat-jan-budaj-dsip.

${ }^{28}$ Ján Budaj as quoted in RUSINOVÁ, Zora. Umenie akcie 1965 - 1989 [The Art of Action 1965 - 1988] (a catalogue to exhibition The Art of Action 1965 - 1989. 26 April - 19 August 2001), pp. 149 - 156. See also EURINGER-BÁTOROVÁ, Andrea. Akčné umenie na Slovensku v 60. rokoch 20. storočia. [Action Art in Slovakia in the 1960s]. Bratislava : Slovart, 2012, pp. 92 - 96. ISBN 978-80-556-0438-1.

${ }^{29}$ BUDAJ, Ján. In RUSINOVÁ, Zora. Akčné umenie na Slovensku v 60. rokoch 20. storočia. [The Art of Action 1965 - 1988] (a catalogue to exhibition Art of Action 1965 - 1989. 26 April - 19 August 2001), p. 150.
} 
Lunches I and II. An artist positions himself between being the creator and an object of his action. He represents live sculpture, the positioning of which, the body position, presents an alarming intervention in terms of everyday reality, and the stereotypical perception of the city.

The group continued exploring public response during a subsequent week, the Week of Fictitious Culture that was held from 21 January to 3 February 1979. Across the city they displayed posters for inexistent exhibitions of René Magritte and Salvador Dalí, and to film premières of Ingmar Bergman; they also posted banners reading "Air transport is most cost-effective." The actions entailed, in part, surrealist mystification. They differed from the rest in that the body of a performer didn't enter the ritual with concealed symbolic values. They were based on direct, immediate presence of man where human body exceeds symbolic representation and becomes both the object and subject of art." 30

As early as in May 1980, the DSIP intended to hold an action Three Sunny Days in the Medical Gardens in Bratislava. "The structure of participants and the type of presentations had a single aim: to create a situation of contact." ${ }^{31}$ The attempt at creating an authentic event was, however, banned by the authorities. The activities of the Labyrinth Theatre were also barred with the staff being dismissed and films screenings banned. Action art became illegal and padlocked until the mid-1980s.

\section{BALVAN Theatre}

After 1985, culture was given new charge: new impulses or neo-expressive forms developed in visual art, music and theatre. Different opinion platforms emerged visà-vis state-prescribed normativity. They played with their own image and ideological syncretism. The unofficial art scene acquired an increasing number of alternative spaces for presentations (home exhibitions, public space, parks, research centres, etc.). Generational ties were rekindled, and the end of the decade also brought new art groups. ${ }^{32}$ One of such innovative platforms was the Balvan Theatre.

Balvan Theatre was officially founded in early January 1987. It followed on the existent group Labyrinth II, which was the remnant of the mime group of Milan Sládek before he emigrated. At the same time, Balvan Theatre picked up on part of Labyrinth I - the theatre of happening, street actions led by Ján Budaj or L'ubomír Ďurček. Michal Murin explains the work of Labyrinth in two lines: "In the first half of the 1980s, the work of Labyrinth II was epitomised by humour. On the other hand, it was influenced by Štefan Hrušovský's participation of at a workshop of the pupils of Jerzy Grotowski in Poland. By 1985 I had already held my first performances, conceptual stage plays, I have written Hry hier [Games of Games] - the manifesto of my intermedia approach to art. I had conceptual visual projects under my belt, I followed the emergence of new media through Ars Electronica in Linz. I was already interested

${ }^{30}$ Ibid., p. 151

${ }^{31}$ Ibid.

${ }^{32}$ BARTOŠOVÁ, Zuzana. Neoficiálna výtvarná scéna na Slovensku. Medzi Chartou '77 a nežnou revolúciou [Unofficial Art Scene in Slovakia: In Between Charter '77 and the Velvet Revolution]. In SNOPKO, Ladislav - BARTOŠOVÁ, Zuzana. Dotyky a spojenia [Touches and Connections]. Bratislava : Orman, 2002, p. 17. ISBN 80967816939788096781690. 
in contemporary music." ${ }^{33}$ When Murin joined forces with Alena Šefčáková, part of the team of Labyrinth II transformed into Balvan Theatre, bringing together Matús Beňo, Eva Miklušičáková, Michal Murin and Alena Šefčáková. It was the first company of experimental theatre - theatre performance that focused on physical theatre, body, movement, non-verbal productions or body-art installations. Balvan Theatre was strongly inspired by the Japanese theatre butoh, The Jerzy Grotowski Theatre, The Antonin Artaud Theatre, by the work of Marina Abramović, and by American avantgarde artists (Robert Wilson, Trisha Brown, The Living Theater). By 1992 the company had held sixty performances.

In February 1986, whilst the team was still with the Labyrinth II, Alena Šefčáková and Michal Murin held, in the Bratislava-based Culture Centre Ovsište, a performance $K R U H$ [CIRCLE]. It was composed as a single-act 3 to 7-minute-long motions with independent composition which essentially reflected the diversity of actors. These principles eventually led to the split of the poetic-lyrical faction (that ended up disintegrating) and the abstract, depth-psychological group. The CIRCLE thus set out, in the 40-minute unit, some 5 or 6 autonomous body compositions. Murin details the performance: "The poetic part of the theatre, conceived by Andrej and Olga Šulgan was dominated by structured and symbolic movement on stage. The poetic ritual atmosphere was completed with candles. Alena Šefčáková presented body etude as an exploration of the potential of a seated body, face and hands, of inner experience of being and its imprint on the body, the study of non-narrative and nondescript, rather intimate, emotional, psychological mimics. My two body compositions paraphrasing musical compositions have been preserved as text. The first, entitled GAVLAS was dramatization of the yin-yang principle, of bipolarity, of the personality split into anima - animus, of the dynamic part of the inside world and the static half of personality. In terms of movement, it was divided by the supple movement of one half of the body and by the tense muscles, by machine-like movement of the other half. The second piece oscillated between an individual movement etude as interpretation of dances by Oskar Schlemmer from the Bauhaus era (based on a single reproduction). Yet, while dancing, I used body and props to generate sounds that culminated in interpretation of percussions and disharmonic movement of the performer placed on them." 34

Within the Slovak context Balvan Theatre proved quite unique. As a strictly sensory theatre, it allowed itself the luxury of authenticity and performative candour of individual protagonists. No comprehensive study, as yet, has been dedicated to Balvan Theatre and its experimental work. Hence, Michal Murin is often critical about the issue: "Balvan brought on Slovak stage such terms as movement theatre or installation performance. The company was more accepted amidst Slovak fine artists than within theatre." ${ }^{35}$ (...) "As if Balvan paid the price of its extraordinary and extreme experimental nature, but also of its intimate individual introverted nature. Slovak theatre studies didn't have at their disposal the terminological database or information that could define what we were actually doing. We made abstract emotional

\footnotetext{
${ }^{33}$ MURIN, Michal - ČAJKOVÁ. Jaroslava. Behom a stopom v pohybe [Running and Hitchhiking, an interview]. In Javisko, 2008, Vol. 40, Issue 3, p. 4.

${ }^{34}$ Ibid.

${ }^{35}$ Ibid., p. 5.
} 


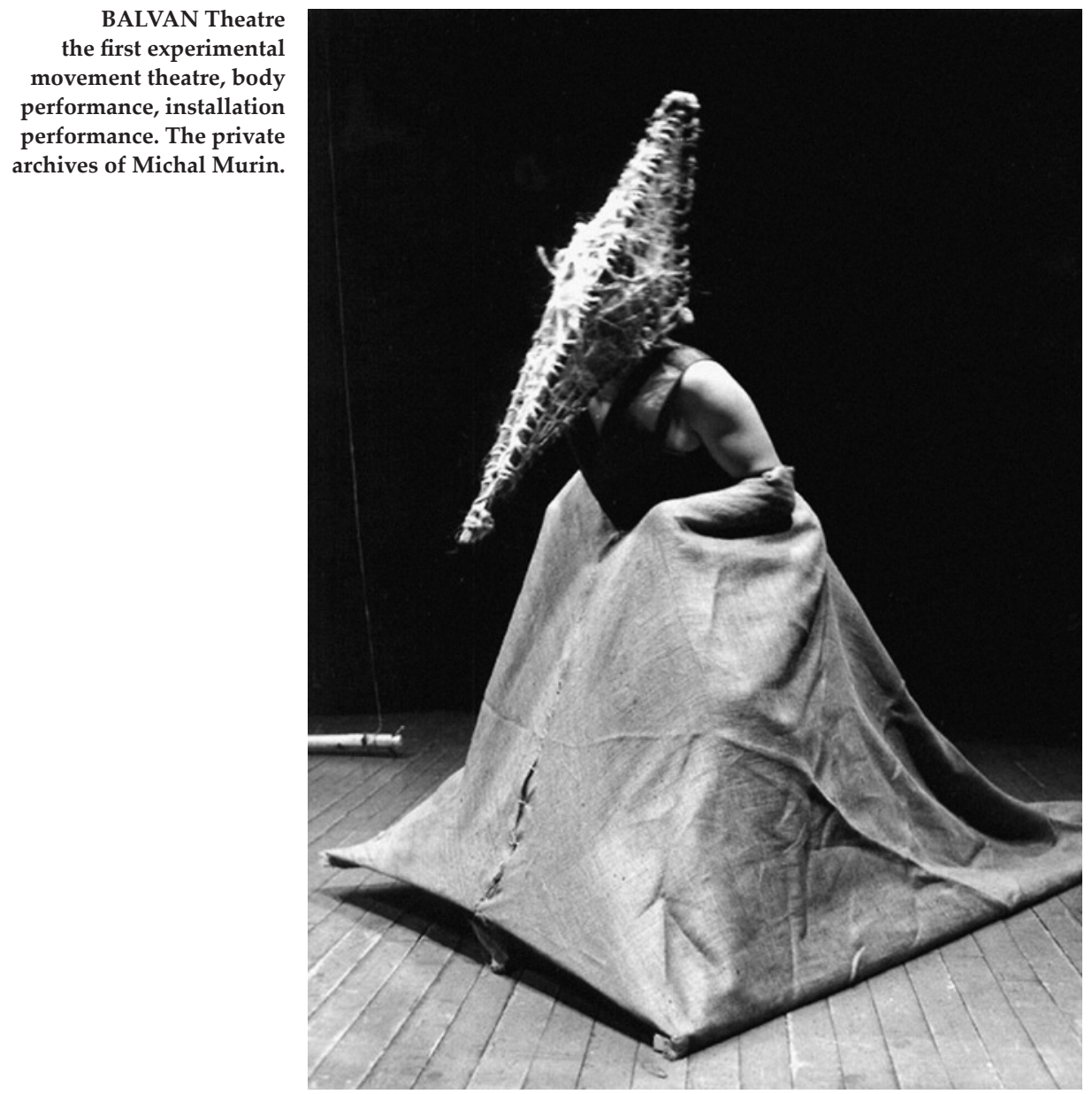

psychological statements. Nonetheless, we didn't use facial mimics, but deformity of face by flexing muscles, exploring body potential, similarly to how it was done in experimental film and video art in the 1970s and early 1980s."36

Another group that, in their actions, largely worked with elements of theatre performance was Spoločnost' pre Pestovanie a Śŕrenie Patafyziky na Slovensku a Iných Svetoch, SpPaŠPnSaIS [The Society for Nurturing and Propagating Pataphysics in Slovakia and Other Worlds based in the city of Trnava. The company consisted of Pero Le Kvet alias Peter Volek and Ján Karásek. During its existence (1988 - 1993), SpPaŠPnSaIS published its pataphysical samizdat publication Bachor [Rumen], and held a range of visual arts, and stage pata actions and happenings. The performances that proved legendary include Rekonštrukcia Mašiny na miškovanie mozgov [The Reconstruction of the Brain Castration Machine] in Trnava, Velká žranica [The Great

${ }^{36}$ VARTECKÁ, Anna. Dimenzia teatrality [The Dimension of Theatricality, exhibition catalogue]. Ústí nad Labem, 2012. 
Grub] in Bratislava, and the exhibitions of the pataphysical company Devätrýchlostný oblačný bicykel [The Nine-Speed Cloudy Bike] in Trnava. ${ }^{37}$ Pero Le Kvet is also the founder of The Alfred Jarry Group (AJG) that was active particularly in the period of $1994-1998$. Its only activity at the time was to publish the pataphysical samizdat publication Mozgomiškár [The Braincastrator]. ${ }^{38}$

The visual artist Miloš Karásek co-founded the Stoka Theatre (1991) together with Blaho Uhlár and co-authored the two Manifestos (the first in 1988). During his time with Stoka Theatre, Karásek created happenings. They are referred to in the study M. Karásek - človek manifestov [M. Karásek - The Man of Manifestos] by the theatre theorist Miloš Mistrík. "At Stoka Theatre, Karásek was largely responsible for visual arts. Yet he wasn't prepared to limit himself to this. Hence, he initiated - still with Blaho Uhlár - happenings in public spaces in the city (Bratislava). In the historical court of the Old Town Hall he stripped actresses, destroyed material fetishes of the new era, spilt milk, engage heavy military equipment in the play. Those were the first steps shortly after the Velvet Revolution, when liberty seemed infinite. Karásek went as far as the very limits of artistic anarchy. Yet he kept his head low and was even capable of self-mockery. During one of the happenings (K.P.B.: Aká si mi krásna... [The Beauty you are...], Bratislava, 25 July 1991) a green military helicopter flew over the spectators, dropping leaf leaflets. Spectators collected them and keenly read: 'What's going on?' The helicopter flew away without an answer, only to return shortly afterwards. It dropped leaflets again. They offered Karásek's ironic answer: 'Nothing.' The puzzled spectators read the leaflets with curiosity. For this was ridicule of their naïve thrill of the new era, of the momentous changes in politics, within the society and in the arts. What happened in fact? The era of wolves dawned; the era of political quarrel; of quick money and dubious businessmen; of fraud and scandals. The old Communists turned coats: many proponents of the previous ideology started promoting the exact opposite openly in public sight. Well then, what was new? Have humans changed? What is going on? Well, nothing new, just the history of mankind is being repeated in a different shape." 39

In 1995, after his departure from Stoka Theatre, Miloš Karásek held a number of actions and happenings. The performance inspired by the elements of mail art Poštové divadlo - Insomnia [Postal Theatre - Insomnia] culminated on 12 December 1995. Karásek recalls: "In 1995 I wrote a short text which I divided into several fragments. They were then printed and placed in special envelopes with a stamp of the Postal Theatre and the number of the fragment. I myself stamped all envelopes. I put together a more-or-less random list of two hundred addressees. Within a precisely set timeframe I started posting them the envelopes. The time schedule and its observation (time articulation) were so important to me, that I had an hour-long meeting with the postal director about the timely delivery. That created sufficient breaks in

${ }^{37}$ The 20-minute documentary Patafunus about the SpPaŠPnSaIS was made in collaboration with the Slovak Television.

${ }^{38}$ See further https://monoskop.org/Bachor.

${ }^{39}$ MISTRÍK, Miloš. Miloš Karásek- človek manifestov [Miloš Karásek - The Man of Manifestos]. In Slovenské divadlo, 2011, Vol. 59, No. 3, p. 222. See also LINDOVSKÁ, Nadežda. Iné divadlo [A Different Theatre]. In INŠTITORISOVÁ, Dagmar. Divadlo - interaktivita, inscenovanost', diskurz [Theatre - Interactivity, Staging Potential, Discourse]. Nitra : Ústav literárnej a umeleckej komunikácie FF UKF, Nitra 2013, pp. 398 - 400. ISBN 978-80-8094-434-6. 


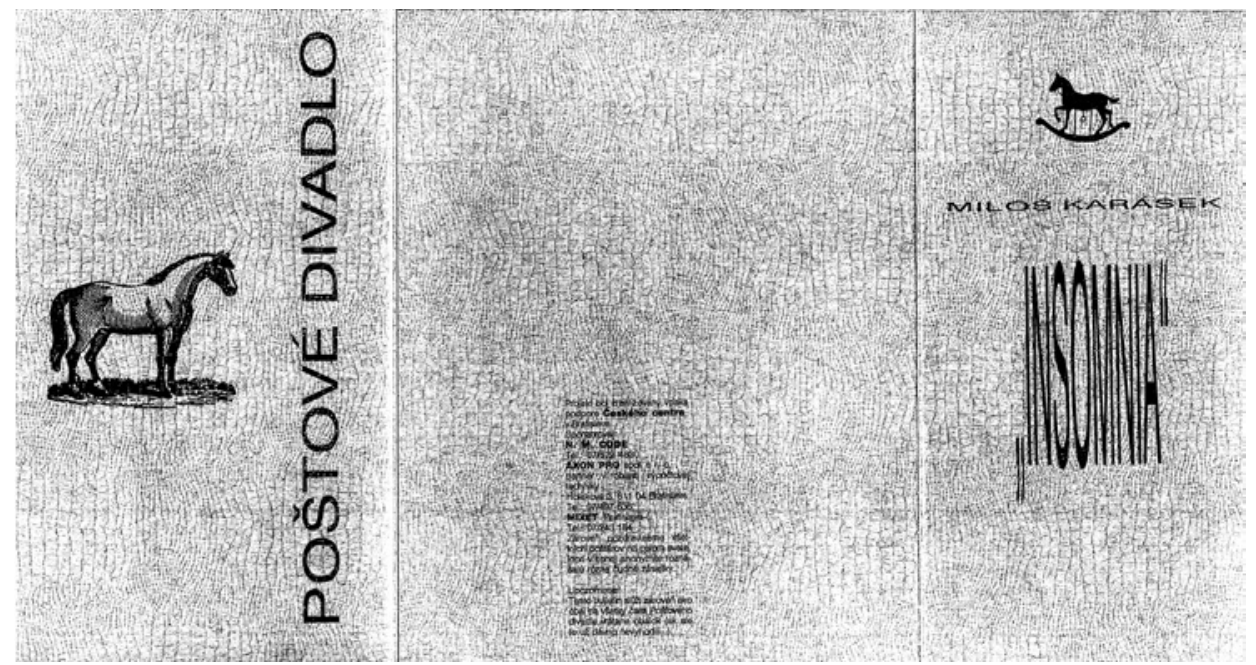

Miloš Karásek: Insomnia. Projekt Poštového divadla [Insomnia: A Postal Theatre Project]. Bratislava, 6 November 2000. The private archives of the authoress.

between individual deliveries; or, on the contrary, they arrived in short sequence. The last, the seventh delivery also contained a creased invitation to the staged finale of the project. The final scene was held on 12 December 1995 on stage at the Czech Centre in Bratislava. On purchase of a ticket at the door, everyone received a bulletin that also served as folder for the fragments. The louder the music grew, the lesser the intensity of light became, until it reached total darkness. I let the spectators sit there for a few minutes. I started to gradually light the stage with a single spot light. In the centre it revealed a barefooted girl with hair that covered her face - Zuzana - Jena Šimková, a virgin at the time. She briefly remained motionless, then I dimmed the light again. I let the spectators sit in darkness for a few minutes. When the spotlight came on again, Zuzana appeared on the same spot, slowly removing her hair from the face, as if she wanted to say something. I dimmed the light and let the spectators sit in darkness for a few minutes. The music grew silent. The lights on stage and in the auditorium suddenly came on. The stage was empty, the auditorium was full. To calm the puzzled spectators, elegant waiters started serving them chilled sparkling wine. The entire fragment lasted 10 minutes and 16 seconds." 40 The departure of Zuzana, who doesn't utter a single sound, was an analogy of Karásek's departure from professional theatre.

What followed were projects L. S. D. in 2001 and, shortly afterwards, a sequel to the performance Postal Theatre entitled Post voyer projekt [Post Voyer Project] in 2002. The Project L. S. D. consists of three-part expositions (food, plays, eroticism) that were gradually presented in three different galleries in Slovakia, Moravia and Bohemia, to culminate with a summary exhibition Unio Mystica in Bratislava. Each part bore its

${ }^{40}$ See KARÁSEK, Miloš. extrakt. pät' projektov [An Extract: Five Projects]. Bratislava : Divadelný ústav, 2004, p. 29. ISBN 80-88987-56-3. 
meta-story accentuated with an installation containing a dominant element (table, swing, bed). The works on display -sculptures by Miloš Karásek and an installation by Juraj Závodný - were accompanied by the ambient by Michal Kořán. The fragmentation and coding of meanings unsettled spectators to a point of making them actively participate in the project.

In the performance Post Voyer Project Karásek made again six invitations with natural motives and a text invitation to the exhibition: within a month, the gallery that was to host the opening, sent them to 300 addressees selected by the artist. Now the texts were a genuine invitation to the opening. They were sent to live recipients (specific persons) and non-live addressees (such as Europe, pedestrian zone, streets). The final batch was an invitation to the collective opening that read: "Celebratory eye opening." Chamber music trio in the corner of vacant Olomouc-based gallery Mona Lisa quietly performed Vivaldi's Four Seasons: Karásek touches upon the theme of nature and human attitude to nature, pointing out to human ignorance and superficiality.

\section{The Future of Performance}

In conclusion, a question arises whether action art or the art of performance as it had been coined and developed within the Slovak context in the late $20^{\text {th }}$ century is now surpassed and a fait accompli. Michal Murin contemplates: "Video performances, video actions, photo actions, video visuals from actions or digital sound art performances have become the lingua franca of the youngest generation of artists. On the other hand, the gradual demise of pure performances is also the result of the adoption of a form of communication with spectators that uses new strategies of visual art. After the turn of millennia, the themes addressed by the performers of the 1970s through to the 1990s have become, in the context of contemporary art, the themes of mainstream exhibition art developments. Action art has been integrated into the neoconceptual art. Hence, two options arise: we shall historically either close down action art (what has indeed been the case repeatedly), or we will speak of action and performable elements / aspects in contemporary art, be them social intervention, activism, oral history, archaeology of social ties and relations, video art - video-action, VJing, visual acoustic interventions in public or gallery space, interactive installations that also require action on the part of spectators, and so on." ${ }^{41}$

Whilst one can agree with Murin, there is a Slovak performative artist whose performance was acquired by Tate Gallery in London in 2004. The acquisition launched the development of the collection People that currently contains twelve works. The performance Good Feelings in Good Times [Dobré pocity v dobrých časoch] by Roman Ondák, follows on Slovak artists from the late 1980s. Ondák himself acknowledges that the inspiration came from the exhibition Suterén [Basement] convened by the art historian Radoslav Matuštík. It presented works by Peter Igor Meluzin, Milan Adamčiak, Július Koller, Peter Rónai, Jana Želibská, Matej Krén, Milan Pagáč and Viktor Oravec. Ondák created his piece following in the footsteps of the tradition of performance, whilst moving it forward. Real situation of people queuing in front of a gallery was turned into fiction. Every day throughout a few weeks, he placed

${ }^{41}$ STOLÁRIK, Michal. Akčné umenie a performance na Slovensku. Rozhovor s Michalom Murinom [Action Art and Performance in Slovakia. An interview with Michal Murin], p. 8. 
Miloš Karásek: Post voyer projekt. [Post Voyer Project]. Mona Lisa Gallery, Olomouc, 30 May 2002. The private archives of the authoress.
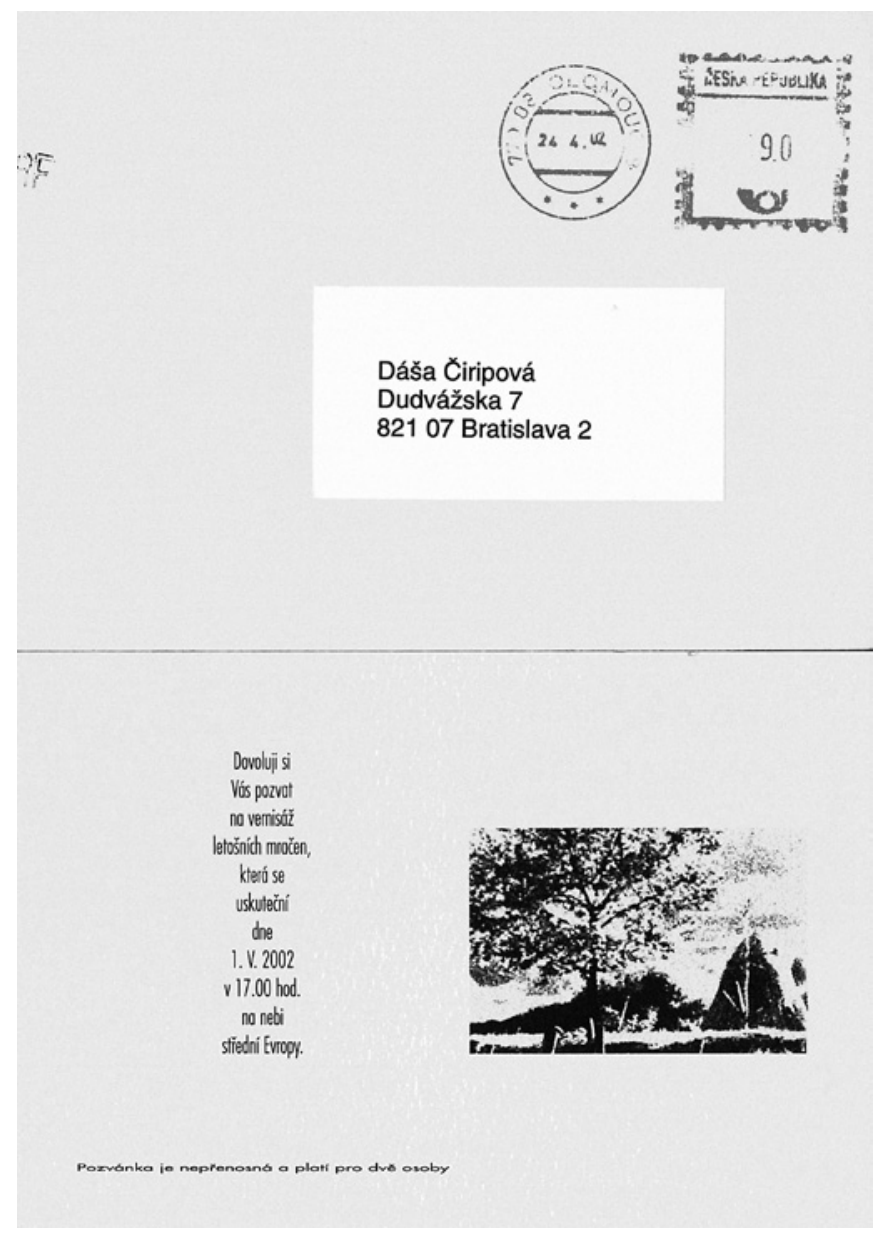

extras in the queue in front of the gallery. That gave rise among ordinary visitors to questions about the sense of waiting and its content. "A number of unclear points arise, and one feels like exploring them along with what kind of art it actually is." 42 To Ondák, conceiving a performance is about imponderability. That, however, is not rooted in the coincidence of a process, but rather in a preformulated idea that encourages spectator curiosity and participation.

The theatricality of public life has its roots in the culture of Ancient Rome. Its communication potential has been and remains the substantial and timeless principle. It appears in public space without us being aware of its presence. The playfulness it contains is a form of survival, whether it applies to the art of the late $20^{\text {th }}$ century or to

${ }^{42}$ NÉMETH, Jana - ONDÁK, Roman. Je prvým Slovákom, ktorého kúpila londýnska Tate Modern. Doma ho takmer nepoznáme [He is the First Slovak to be Acquired by Tate Modern. Yet He Is Virtually Unknown at Home]. An interview in Denník N, 26 December 2015. Available at https://dennikn.sk/326136/ prvy-slovak-ktoreho-kupila-londynska-tate-modern/ (cit. on 15 June 2018). 
the present day, when performance has become a routine form of expression in visual arts, as well as in theatre. Playfulness, the removal of the limits between the performer and the spectator, or the changing method of work with sign make us redefine art, its role and purpose. A creative process arises from authenticity, non-illusiveness and from capturing reality that, simultaneously, can also be a fiction. What matters is presence, situation and an intense moment.

The study is an output of the grant project VEGA 2/0170/16 - Theatre as a Communication of the Crisis of Values.

Translated by Lucia Faltin

Dáša Čiripová

Ústav divadelnej a filmovej vedy CVU SAV

Dúbravská cesta 9

84101 Bratislava

Slovakia

e-mail: dasaciripova@yahoo.com 